\title{
Efficacy of Co-Synch plus CIDR and Double PG plus GnRH Protocols in Repeat Breeder Cows
}

\author{
Sanjeevkumar S. Patil", M. K. Tandle, R. G. Bijurkar, N. A. Patil, \\ Dilip Kumar, Shrikant Kulkarni and S. Naveen Kumar
}

Veterinary College, KVAFSU, Nandinagar, Bidar, Karnataka, India

*Corresponding author

\section{A B S T R A C T}

\section{Keyw ords \\ Co-Synch plus CIDR protocol, Double PG plus GnRH protocol, Oestrus synchronization, Repeat breeder cows, Conception rate}

Article Info

Accepted: 12 December 2020 Available Online: 10 January 2021
The present research was conducted to compare the efficacy of Co-Synch plus CIDR versus Double PG plus GnRH protocol in repeat breeder (RB) cows. A total of $1476 \mathrm{RB}$ cows were selected after thorough gynaeco-clinical examination and were dewormed (Inj.Dectomax ${ }^{\circledR} @ 1 \mathrm{ml} / 50 \mathrm{~kg}$ bodyweight $\mathrm{S} / \mathrm{C}$ ) followed by mineral mixture (Powder Lacton $^{\circledR} 50 \mathrm{~g} /$ day orally) supplementation for 30 days. Then these RB cows were either assigned to Co-Synch plus CIDR protocol ( $n=614$; wherein on day ' 0 ':inj. GnRH (Busereline acetate $10 \mu \mathrm{g} \mathrm{I} / \mathrm{M}$ ) and Controlled Internal Drug Release (CIDR) implant was inserted into the vagina and kept in situ for 7 days, on day '7': CIDR removed and inj. PGF2 $\alpha$, (Dinoprost Tromethamine $25 \mathrm{mg} \mathrm{I} / \mathrm{M}$ ) was given, day '9': inj. GnRH (Busereline acetate $10 \mu \mathrm{g} \mathrm{I} / \mathrm{M}$ ) and insemination (AI) was done. Further, on the day ' 10 ' if any signs of oestrus then, a second AI was done) or Double PG plus GnRH protocol ( $\mathrm{n}=862$; wherein on day'0’: inj. PGF2 $\alpha$ (Dinoprost Tromethamine $25 \mathrm{mg} \mathrm{I} / \mathrm{M}$ ), oestrus detection from $2^{\text {nd }}$ to $5^{\text {th }}$ day and insemination was done along with inj. GnRH (Busereline acetate $10 \mu \mathrm{g} \mathrm{I} / \mathrm{M}$ ), again PGF2 $\alpha$, (Dinoprost Tromethamine $25 \mathrm{mg} \mathrm{I} / \mathrm{M}$ ) was administered on $11^{\text {th }}$ day to nonresponders and oestrus detection from $13^{\text {th }}$ to $16^{\text {th }}$ day and insemination was done along with inj.GnRH (Busereline acetate $10 \mathrm{mg} \mathrm{I} / \mathrm{M}$ ). Pregnancy diagnosis was performed on $60^{\text {th }}$-day post-AI by per-rectal examination. The conception rates were found to be 50.97 , 36.04 and 11.11 per cent for RB cows of Co-Synch plus CIDR protocol and 49.65, 29.87 and 10.75 per cent for RB cows of Double PG plus GnRH protocol in first, second and third oestrus cycles respectively, achieving overall conception rate of 63.68 and 56.15 per cent in RB cows of Co-Synch plus CIDR protocol and Double PG plus GnRH protocol, respectively. It is concluded from the present study that, Co-Synch plus CIDR protocol is better than the Double PG plus GnRH protocol for the treatment of repeat breeder cows.

\section{Introduction}

Repeat breeding is one of the exasperating reproductive disorders of cows and buffaloes, which results in heavy economic loss to dairy farmers. The incidence of repeat breeding has been reported to be ranging from 5 to 30 per cent (Bartlett et al., 1986; Moss et al., 2002 and Yusuf et al., 2010). The incidence of repeat breeding was far higher in crossbred cattle $(17.57 \%)$ as compared to buffaloes $(12.74 \%)$ and indigenous cattle $(8.64 \%)$. The 
incidence of repeat breeding in India has been reported from 19.19 (Karwani and Sharma, 2003) to 45.15 per cent (Kumar et al., 2010) in cattle.

Generally, oestrus synchronization is achieved by two approaches. The first approach is by controlling the luteal phase of the cycle either through the administration of prostaglandins (Brito et al., 2002) or by using progesterone analogues (Rensis et al., 2005). However, the prostaglandins have limitation like it would work only if a corpus luteum is present (Chohan, 1998; Brito et al., 2002).

Controlled Internal Drug Release (CIDR) is another most recent hormone device available where progesterone is released from CIDR at a controlled rate into the bloodstream of the animal through the vagina and suppresses oestrus and ovulation throughout its duration in situ (Lucy et al., 2001). The CIDR device was developed by Macmillan et al., 1991 and it is well adopted in synchronizing oestrus consistently, which has resulted in high pregnancy rates in cattle regardless of the stage of the oestrus cycle. This CIDR can be used in combination with other hormones to synchronize oestrus in cows and buffaloes (Lamb, 2010). Therefore, the present research work was undertaken to compare the efficacy of Co-Synch plus CIDR protocol versus Double PG plus GnRH protocol in repeat breeder cows.

\section{Materials and Methods}

The research was conducted under field conditions in the selected villages of Bidar district in collaboration with the Department of Animal Husbandary \& Veterinary Services, Bidar and Department of Gynaecology and Obstetrics, Veterinary College, Bidar, Karnataka state, India from August 2016 to December 2018. Geographically, Bidar district is located in
North Interior Karnataka at $17^{0} 35^{\prime}$ to $18^{0} 25^{\prime}$ North latitude and $76^{\circ} 42^{\prime}$ to $77^{\circ} .39^{\prime}$ East longitudes at an elevation of 640 to 715 meters above the mean sea level.

\section{Selection of repeat breeder cows}

The gynaeco-clinical health check-up camps were conducted and repeat breeder cows were selected from five talukas of Bidar district after ruling out infectious infertility, anatomical defects and any other pathological conditions. A total of 1476 repeat breeder cows were selected and were dewormed (Inj.Dectomax ${ }^{\circledR} @ 1 \mathrm{ml} / 50 \mathrm{~kg}$ bodyweight S/C) and supplemented with mineral mixture powder (Lacton ${ }^{\circledR} 50 \mathrm{~g} /$ day orally) for 30days. Then, repeat breeders were assigned randomly either Co-Synch plus CIDR protocol or Double PG plus GnRH protocol under controlled breeding. The various veterinary products used for the present study are listed in Table-1.

\section{Co-Synch plus CIDR protocol}

Controlled Internal Drug Release (CIDR) was inserted intravaginally and kept in situ for 7 days and injection of GnRH (Busereline acetate $10 \mu \mathrm{g} \quad \mathrm{I} / \mathrm{M}$ ), PGF2 $\alpha$ (Dinoprost Tromethamine $25 \mathrm{mg} \mathrm{I} / \mathrm{M}$ ) and Fixed Time Insemination (FTAI) was carried out as shown in the flow chart (Figure 1).

\section{Double PG plus GnRH protocol}

Administration of the first PGF2 $\alpha$ (Dinoprost Tromethamine $25 \mathrm{mg} \mathrm{I} / \mathrm{M}$ ), oestrus detection, insemination and injection GnRH (Busereline acetate $10 \mu \mathrm{g} \mathrm{I} / \mathrm{M})$, second PGF2 $\alpha$, (Dinoprost Tromethamine $25 \mathrm{mg} \mathrm{I} / \mathrm{M}$ ) given on $11^{\text {th }}$ day to non-responders and insemination and injection GnRH (Busereline acetate $10 \mathrm{mg} \mathrm{I} / \mathrm{M}$ ) was carried out as depicted in the flow chart (Figure 2). 


\section{Conception rate and fertility}

All the inseminated cows were monitored regularly and those cows which did not return to oestrus between 18-24 days post-AI were subjected to pregnancy diagnosis by rectal palpation after 60 days of insemination. First, second and third service conception rates were calculated separately for cows by the percentage of cows found pregnant out of total cows inseminated at first, second or third oestrus. Overall conception rate was calculated by the percentage of cows found pregnant out of the total number of cows inseminated at first, second and third oestrus. Conception rate was calculated in percentage and Chi-square analysis was done for conception rate between first, second and third oestrus cycle's inseminations in Co-
Synch plus CIDR and Double PG plus GnRH protocol for fertility.

\section{Results and Discussion}

The repeat breeder cows of Co-Synch plus CIDR oestrus synchronization protocol showed $100 \%$ ( $\mathrm{n}=614)$ oestrus response and conception rate was 50.97, 36.04 and 11.11 per cent in first, second and third oestrous cycles with an overall conception rate of 63.68 per cent. Similarly, repeat breeder cows of Double PG plus GnRH oestrus synchronization protocol also showed 100 per cent $(\mathrm{n}=862)$ oestrus response. However, conception rate was lower at 49.65, 29.87 and 10.75 per cent in first, second and third oestrous cycles, respectively with an overall conception rate of 56.15 per cent. (Table 2).

Table.1 Drugs and products used for controlled breeding programme in bovines

\begin{tabular}{|c|c|c|}
\hline $\begin{array}{l}\text { Sl. } \\
\text { No. }\end{array}$ & $\begin{array}{l}\text { Name of the } \\
\text { product }\end{array}$ & Composition \\
\hline 1 & Inj.: Dectomax ${ }^{\circledR}$ & Doramectin $10 \mathrm{mg} / \mathrm{mL}$ \\
\hline 2 & Powder: Lacton ${ }^{\circledR}$ & $\begin{array}{l}\text { Each } 100 \mathrm{~g} \text { contain: } \\
\text { Niacin: } 30 \mathrm{mg} \\
\text { Sulphur: } 200 \mathrm{mg} \\
\text { Iron: } 200 \mathrm{mg} \\
\text { Calcium Lactate: } 12.5 \mathrm{~g} \\
\text { Sodium Lactate: } 12.5 \mathrm{~g} \\
\text { Sodium Propionate: } 12.0 \mathrm{~g} \\
\text { Base fortified with live } \\
\text { yeast cells as QS. }\end{array}$ \\
\hline 3 & Inj.: Gynarich ${ }^{\circledR}$ & $\begin{array}{l}\text { Busereline acetate } \\
\text { (GnRH analogue) } \\
4 \mu \mathrm{g} / \mathrm{mL}\end{array}$ \\
\hline 4 & Inj.: Lutalyse ${ }^{\circledR}$ & $\begin{array}{l}\text { Dinoprost Tromethamine } \\
5 \mathrm{mg} / \mathrm{mL}\end{array}$ \\
\hline 5 & $\begin{array}{l}\text { EAZI-BREED } \\
\text { CIDR }{ }^{\circledR} \text { Cattle } \\
\text { Insert }\end{array}$ & $\begin{array}{l}\text { Progesterone, } 1.38 \text { gram } \\
\text { per each EAZI-BREED } \\
\text { CIDR Cattle Insert. }\end{array}$ \\
\hline
\end{tabular}


Table.2 Efficacy of Co-Synch plus CIDR protocol and Double PG plus GnRH protocol oestrus synchronization on fertility in repeat breeder cows

\begin{tabular}{|c|c|c|c|c|c|c|}
\hline \multirow[t]{2}{*}{ Protocol } & \multirow{2}{*}{$\begin{array}{c}\text { Oestrus } \\
\text { response } \\
\%\end{array}$} & \multicolumn{5}{|c|}{ Conception rate (\%) } \\
\hline & & $\begin{array}{l}\text { First } \\
\text { cycle }\end{array}$ & $\begin{array}{l}\text { Second } \\
\text { cycle }\end{array}$ & $\begin{array}{l}\text { Third } \\
\text { cycle }\end{array}$ & $\begin{array}{l}\text { Chi-square } \\
\text { value and df }\end{array}$ & Overall \\
\hline $\begin{array}{l}\text { Co -Synch plus CIDR } \\
(n=614)\end{array}$ & 100 & $\begin{array}{l}(313) \\
50.97\end{array}$ & $\begin{array}{c}(71) \\
36.04\end{array}$ & $\begin{array}{c}(7) \\
11.11\end{array}$ & $13.9 * *, 2$ & $\begin{array}{l}(391) \\
63.68\end{array}$ \\
\hline $\begin{array}{l}\text { Double PG plus } \\
\text { GnRH (n=862) }\end{array}$ & 100 & $\begin{array}{l}(428) \\
49.65\end{array}$ & $\begin{array}{c}(46) \\
29.87\end{array}$ & $\begin{array}{c}(10) \\
10.75\end{array}$ & & $\begin{array}{l}(484) \\
56.15\end{array}$ \\
\hline
\end{tabular}

Note: The values in the parentheses indicates number of cows

$* *$ Highly significant at $\mathrm{p}<0.01$

Fig.1 Co-Synch + CIDR protocol

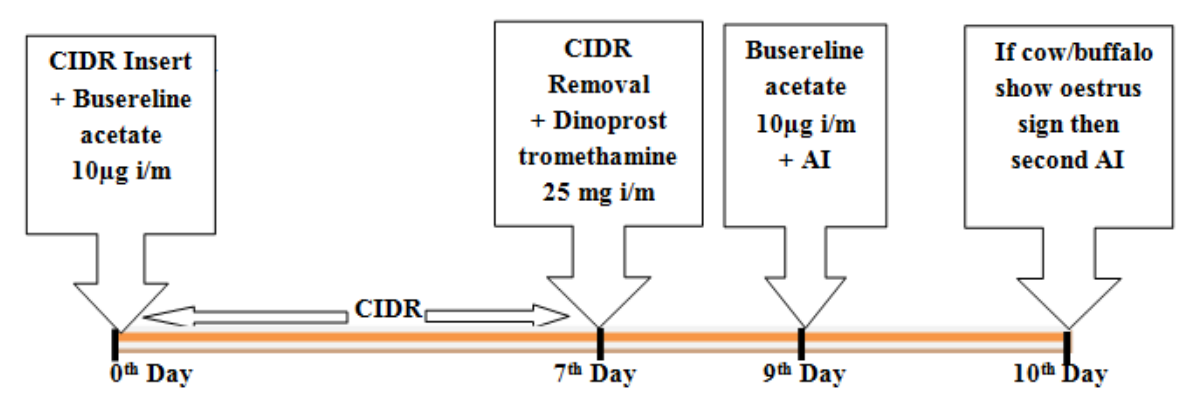

Fig.2 Double PG + GnRH protocol

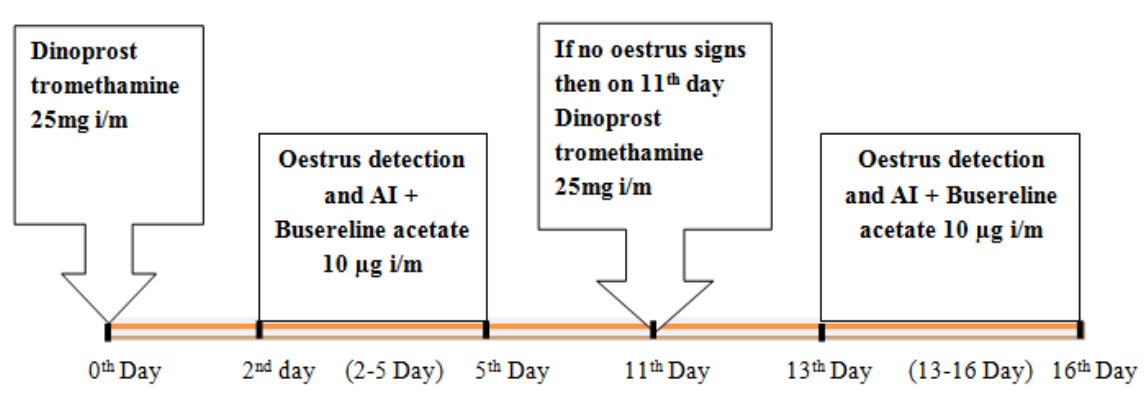

The conception rate for Co-Synch plus CIDR treated repeat breeder cows in first, second and third estrous cycle's compared to Double PG plus GnRH treated repeat breeder cows was highly significant $(\mathrm{p}<0.01)$ and further, the overall conception rate for $\mathrm{Co}-\mathrm{Synch}+$ CIDR was higher (63.68\%) compared to Double $\mathrm{PG}+\mathrm{GnRH}$ treated repeat breeder cows $(56.15 \%)$.
Comparable to the present study, Jayaganthan et al., (2016) in repeat-breeding crossbred Jersey cows used Ovsynch alone or Ovsynch plus CIDR and compared with control and reported pregnancy rate of 54.54, 72.72 per cent and 27.27 per cent, respectively. Sarath et al., (2019) also reported conception rate of 69.32 per cent in Jersey crossbred repeat breeder cows with progesterone impregnated 
intra-vaginal device (TRIU-B, Virbac, India)cloprostenol sodium- protocol. In addition, Rajkumar et al., (2018) recorded first service conception rate in CIDR + PGF $2 \alpha$ treatment group as 58.33 per cent whereas, 33.33 per cent in control group in repeat breeding crossbred Jersey cows. In contrast, Kim et al., (2007) recorded lower pregnancy rate of 18.5 and 32.1 per cent in repeat breeder cows using CIDR-oestradiol benzoate + progesteronePG- oestradiol benzoate and CIDR-GnRHPG-GnRH protocols, respectively. ElTarabany and AL-Marakby (2018) also recorded poor pregnancy per AI at 28 days post insemination as 28.75 per cent in multiparous repeat breeder Holstein cows using CIDR synch protocol.

Present study findings for Double PG plus GnRH protocol are line with Parmar et al., (2015) who recorded pregnancy rate in repeat breeding cows $(n=10)$ at first service and overall pregnancy rate as 40 and 60 per cent, respectively for mid-cycle PGF $2 \alpha$ protocol, further Ghuman et al., (2012) recorded the first service conception rate of 66.7 per cent for repeat-breeder crossbred dairy cows with a prostaglandin $\mathrm{F} 2 \alpha$-gonadotrophin releasing hormone (PGF2 $\alpha-\mathrm{GnRH})$ fixed-time artificial insemination (AI) protocol at the late luteal phase.

The prolonged exogenous progesterone priming from CIDR device might have caused negative feedback effect on hypothalamichypophyseal-gonadal axis and increased receptors for gonadotrophin on the ovaries followed by rebound on its sudden withdrawal causing stimulated FSH secretion, folliculogenesis and ovulation which has resulted in the higher conception rate with CIDR protocol (Naikoo et al., 2016). Further, it can be concluded from the study that CoSynch plus CIDR protocol is better than Double PG plus GnRH protocol for the treatment of repeat breeder cows.

\section{References}

Bartlett, P.C., Kirk, J. H. and Mather, E. C., 1986. Repeated insemination in Michigan Holstein Friesian cattle: incidence, descriptive epidemiology and estimated economic impact. Theriogenology., 26: 309-322

Brito, L.F.C., Satrapa, C.R., Marson, E.P. and Kastelic, J.P., 2002. Efficacy of PGF2 $\alpha$ to synchronize estrus in water buffalo cows (Bubalus bubalis) is dependent upon plasma progesterone concentration,corpus luteum size and ovarian follicular status before treatment. Animal Reproduction Science., 73(1-2): 23-35

Chohan,K.R,. 1998. Estrus synchronization with lower dose of $\mathrm{PGF} 2_{\alpha}$ and subsequent fertility in subestrus buffaloes. Theriogenology., 50 (7):1101-1108

El-Tarabany, M.S. and Al-Marakby, K.M., 2018. Effect of synchronization protocols on reproductive indices, progesterone profile and fertility under subtropical environmental conditions in repeat breeder Holstein cows. Reproduction in domestic animals., 54(2):234-242

Ghuman, S. P. S, Honparkhe, M. and Singh, J., 2012. Impact of initiating a PGF2 $\alpha$ $\mathrm{GnRH}$ fixed-time AI protocol at the late luteal phase on reproductive performance of repeat-breeder crossbred dairy cattle., Indian Journal of Animal Sciences., 82 (8):830-833

Jayaganthan. $\quad$ P., $\quad$ Vijayarajan.A., Prabaharan.V., Rajkumar.R., Sivakumar.A and Raja,S., 2016. Effect of Ovsynch plus CIDR protocol in management of repeat breeding crossbred Jersey cows. International Journal of Science, Environment and Technology., 5 (6): 3707 3712

Karwani, A. and Sharma, J.K., 2003 Incidence and epidemiology of abortions and repeat breeding in bovines at dairy farms in Punjab, India. In The $11^{\text {th }}$ 
international symposium of the world association of veterinary laboratory diagnosticians and oie seminar on biotechnology., November. pp 9-13

Kim, U.H., Suh, G.H., Hur, T.Y., Kang, S.J., Kang, H.G., Park, S.B., Kim, H.S. and Kim, I.H., 2007. Comparison of two type of CIDR based timed artificial insemination protocols for repeat breeder dairy cows. Journal of Reproduction and Development, 53(3): 639-645

Kumar, R., Dhami, A.J., Butani, M., Kavani, F.S., Sarvaiya, N.P. and Ankita, K., 2010. Management of repeat breeding under field conditions using hormonal and nonhormonal drugs in cows. Indian J. Anim. Reprod., 31(1):30-32

Lamb, G. C., Dahlen, C. R., Larson, J. E., Marquezini, G. and Stevenson, J. S., 2010. Control of the oestrous cycle to improve fertility for fixed-time artificial insemination in beef cattle: a review. $J$. Anim. Sci., 88(13 Suppl): E 181-192

Lucy, M.C., Billings, H.J., Butler,W.R., Ehnis, L.R., Fields, M.J., Kesler, D.J., Kinder,J.E., Mattos, R.C., Thatcher, W.W., Wettemann, R.P., Yelich, J.V. and Hafs, H.D., 2001. Efficacy of an intra vaginal progesterone insert and an injection of PGF $2 \alpha$ for synchronizing estrus and shortening the interval to pregnancy in postpartum beef cows, peripubertal heifers and dairy heifers. J. Anim. Sci., 79: 982995

Macmillan, K.L., Taufa, V.K., Barnes, D.R. and Day, A.M., 1991. Plasma progesterone concentration in heifers and cow treated with a new intar vaginal device. Anim Reprod Sci., 21: 25-40

Moss, N., Lean, I. J., Reid, S. W. J. and Hodgson, D. R., 2002. Risk factors for repeat-breeder syndrome in New South Wales dairy cows. Prev Vet Med 54: 91103.
Naikoo, M., Dhami, A.J. and Ramakrishnan, A., 2016. Effect of estrus synchronization on plasma progesterone profile and fertility response in postpartum suckled anestrous Kankrej cows. Indian $J$ Anim Research., 50(4):60-465

Parmar, P.C., Patel, D.M., Hadiya, K.K., Dhami, A.J., Buhecha K.V. and Sarvaiya, N.P., 2015. Fertility and plasma progesterone profile in repeat breeding cows and buffaloes in ovsynch and midcycle PGF $2 \alpha$ treatment protocols. Indian $J$ Anim Reprod., 36 (2): 1-3

Rajkumar R, Vijayarajan A, Jayaganthan P, Prabaharan V, Raja S and Palanisamy M., 2018. Effect of controlled breeding using CIDR and PGF $2 \alpha$ on fertility in repeat breeding crossbred cows. International Journal of Science, Environment and Technology., 7 (6): 1998 - 2003

Renis, F.D., Ronci, G., Guarneri, P., Nguyen, B.X., Presicce, G.A., Huszenicza, G. and Scaramizzi, R.J., 2005. Conception rate after fixed timed insemination following ovsynch protocol with and without progesterone supplementation in cyclic and non-cyclic Mediterranean Italian Buffalo (Bubalus bubalis). Theriogenology., 63 (7): 1824-1831

Sarath, T., Joseph, C., Veeramani, P., Jeya, J.T., Chemmalar, S., Pugazharasi, C., Sureshkumar, R. and Gopikrishnan, D., 2019. Progesterone impregnated intravaginal device and timed artificial insemination (TAI) on fertility in repeat breeding Jersey crossbred cows. Indian J. Anim. Sci., 89(8): 853-854

Yusuf, M., Nakao, T., Ranasinghe, R. B. K., Gautam, G., Long, S. T., Yoshida, C. and Hayashi, A., 2010. Reproductive performance of repeat breeders in dairy herds. Theriogenology., 73(9): 1220-1229 


\section{How to cite this article:}

Sanjeevkumar S. Patil, M. K. Tandle, R. G. Bijurkar, N. A. Patil, Dilip Kumar, Shrikant Kulkarni and Naveen Kumar, S. 2021. Efficacy of Co-Synch plus CIDR and Double PG plus GnRH Protocols in Repeat Breeder Cows. Int.J.Curr.Microbiol.App.Sci. 10(01): 1623-1629. doi: https://doi.org/10.20546/ijcmas.2021.1001.189 